\title{
The Effect of Learning Strategy and Thinking Ability on The Students' Learning Outcomes in Economics Subject of XI Social Students in Senior High School State 1 in Pematang Siantar
}

\author{
Herna Valentina Sitorus ${ }^{1}$, Eko Wahyu Nugrahadi ${ }^{2}$, Kustoro Budiarta ${ }^{2}$ \\ ${ }^{1}$ Postgraduate Faculty, State University of Medan (Unimed), Indonesia \\ ${ }^{2}$ Lecturer in State University of Medan (Unimed), Indonesia \\ valengratia@gmail.com
}

\begin{abstract}
The purpose of this research is to: (1) know the comparison of economic learning outcomes of students who taught with inquiry learning strategies by using internet media and expository learning strategies using internet media, (2) know the comparison of economic learning outcomes of students who have the ability to high order thinking skills and who have the ability to low order thinking skills, and (3) know the interaction between learning strategies and thinking skills on economics subject learning outcomes. The population in this research were all students of XI Social students in Senior High School State 1 in Pematang Siantar which consisted of 4 classes. The sampling technique used a purposive sampling method so that 2 classes sample are obtained with each of 30 students. This research used an experimental method with an instrument in the form of learning outcomes tests and a questionnaire validation of economic learning outcomes test. The analysis data used $2 \times 2$ factorial Anava. The results of this research showed that: (1) the students' learning outcomes on economics subject taught with inquiry learning strategies using internet media are higher than the economic learning outcomes of students taught with expository learning strategies using internet, (2) the results of the students' learning outcomes who have high order thinking skills are higher than the outcomes of students who have low order thinking skills ability, and (3) there is an interaction between learning strategies and the ability to think on the learning outcomes of the economics subject. The results of the research are expected to provide information for teachers and schools in implementing learning strategies by using internet media and students' thinking abilities to improve the students' learning outcomes on economics subject of XI Social students.
\end{abstract}

Keywords: Learning Strategies; Thinking Ability and Learning Outcomes on Economics Subject

\section{Introduction}

Education is one way to produce quality Human Resources (HR) with experience changes in knowledge, skills and attitudes. These changes can be a capital to improve selfcompetence in facing the era of globalization that always undergo the change. The development of technology and information has had a significant influence on society. Fast, broad, and open access for information that is fast, can be utilized to obtain various information needed including in the world of learning.

Changes in the learning process are closely related to 21 st century skills. Fadel (2008) states that the learning and innovation skills needed in the 21 st century are known as $4 \mathrm{C}$, namely: (1) Creativity, (2) Critical thinking, (3) Collaboration (the ability to collaborate), and (4) Communication (communication skills). Society in the 21 st century realizes the importance of preparing young people who are creative, able to think critically, have a personality, be able to analyze a variety of choices - choices that exist, are skilled at solving problems and making 
decisions correctly. Therefore, schools are expected to produce graduates who are competitive in the world of work.

The ability to think at a high level is also important in the development of industry learning 4.0, which is using internet media as a way of learning based on digital technology. The internet can be said to be the window of world information. Rusman (2012: 48), states that, "the internet is a giant library of the world, because on the internet there are billions of sources of information."

The use of internet media has been utilized by everyone in all corners of the world in various interests. "The internet using is as a source information and communication and media". Students also use it as a tool of communication. The media students need to be made more conscious about handling the information they reach on the internet and be trained about how to deal with the enormous amount of information they have access to through the new technologies".(Ozad \& Kutoglu, 2010: 253)

Based on the observations made at Senior High School State 1 in Pematangsiantar on Economics subject, competency standards have not been reached optimally. This can be seen from the table of the average semester of XI Social students exam grades in the last three years with KKM (Minimum completeness criteria) 72.

Table 1. Average Grade XI IPS Social Sciences Semester Test

\begin{tabular}{|c|c|c|c|}
\hline No & Subjects & School Years & Average Value \\
\hline 1 & Economics & $2015 / 2016$ & 68.55 \\
\hline 2 & Economics & $2016 / 2017$ & 70.52 \\
\hline 3 & Economics & $2017 / 2018$ & 72.28 \\
\hline
\end{tabular}

Source: Administrations of Senior High School State 1 in

Pematang Siantar, Kab. Simalungun

In the table above, it shows the economic learning outcomes of students of class XI IPS still did not achieve the maximum results, Even though in the academic year of 2017/2018, they had reached KKM. Another indicator that shows the inability of students to master economic learning competencies is the low economic learning outcomes of students due to the learning process that is applied only to measure cognitive abilities so that most students learn to think of economics as a difficult and boring lesson and the lack of students' ability to think in examine and answer existing problems.

In addition, the learning strategies carried out so far tend to use less varied lecture methods that are interspersed only with questions and answers and assignments. With this method students get one-way information sourced from the teacher only. Teachers do more (teacher's center), causing students to be less motivated in learning and less interested in participating in economic learning.

Based on this situation, the teacher should take the steps to make learning active and enjoyable again so that students have adequate knowledge and skills, such as the use of media, models, strategies, methods, approaches, teacher teaching styles and student learning styles that enable them to be more active, critical and skilled during learning takes place. One of the steps that teachers can take is to apply inquiry learning strategies.

The stages of inquiry learning strategies train students to improve their thinking abilities. The ability to think in humans is grouped into two, namely the High Order Thinking Skills (HOTS) and Low Order Thinking Skills (LOTS). HOTS ability is the ability to apply to the students' thinking processes skill fully and logically where students have preliminary knowledge related to problems and can make appropriate choices in overcoming the problems 
encountered while LOTS ability is the ability to think mechanically and is limited to routine things such as remembering and understand.

Alpindo (2014) suggests that giving HOTS questions with appropriate learning strategies can improve the cognitive realm of students. HOTS is the ability to analyze and solve problems by thinking critically and creatively. For this reason, it is necessary to design a learning strategy that is more effective, efficient and attractive to improve students' thinking. Marshall \& Harton (2011) say that "Higher Order Thinking Skills (HOTS), such as logical thinking, critical thinking and reasoning skills are the basic skills for daily life, apart from the academic achievements in the schools.

Based on the description above, one way to improve students on Economic subject outcomes requires a learning strategy that provides learning experiences not only obtained through learning books but can also involve the use of internet media as a large and accessible source of information at any time so as to enhance students' thinking abilities in solving problems he faces. The use of inquiry learning strategies and HOTS capabilities are a few of the ways that are expected to improve students' learning outcomes on Economics subject. For this reason, researchers are interested in conducting research with the title "The Effect of Learning Strategies and Thinking Ability on The Students' Learning Outcomes in Economics Subject of XI Social Students in Senior High School State 1 in Pematang Siantar".

\section{Review of Literature}

\subsection{The Nature of Learning and Learning Outcomes in Economics}

Learning is the process of changing behavior due to interactions among individuals and the environment. Changes in behavior include changes in knowledge, understanding, attitudes, skills, motivation, interests, thinking abilities and so on. Suparman (2012: 16), argues that "learning is a process of behavior change that can be observed by others including by teachers". Dwidayani (2013:55) states that, "Learning outcomes are measures of success or failure of students after taking teaching and learning activities both in terms of effective, psychomotor, and cognitive which includes knowledge (memory, understanding, application (application)". Learning outcomes are a form of achievement students as well as a symbol of the success of educators in learning students (Yusuf, 2015: 181).

Economics is one of the subjects taught at the high school level. Economics in the learning process is a subject that is taught about how human efforts to find the right choice in utilizing limited resources for survival. The extent of economics and the limited time available makes these competency standards and basic competencies limited and focused on economic empirical phenomena that occur around the environment and take advantage of a better life (Kemdikbud, 2014: 18). From the description above, it can be concluded that economic learning is an activity intended to deepen student mastery in economics through teaching and learning activities in class. Thus, economic learning outcomes are the results obtained by students after participating in teaching and learning activities on economic subjects so that students have changes in cognitive, affective, and psychomotor aspects through the evaluation of learning conducted. 


\subsection{The Nature of Inquiry and Expository Learning Strategies Using Internet Media}

According Miarso (2009: 530), a learning strategy is a holistic approach to learning in a learning system situation, which is in the form of general guidelines and a framework of activities to achieve the general objectives of learning and are elaborated from the view of certain philosophies and or learning theories. Learning strategies are learning activities that must be done by teachers and students so that learning objectives can be achieved effectively and efficiently (Sanjaya, 2008: 126). Thus it can be concluded that the learning strategy is a series of learning steps chosen by the teacher in delivering learning material so that it makes it easier for students to accept and understand the lessons that ultimately the learning objectives can be mastered at the end of learning activities. In this study, researchers used inquiry and expository learning strategies. Both of them involved the use of internet media as the independent variable.

Inquiry learning strategy (SPI) is a series of learning activities that emphasize the process of thinking critically and analytically to seek and find answers to a problem in question (Sanjaya, 2008: 196). Thus Baker (2008), states that," inquiry based learning (IBL) is to require students to explore and urgen them to think and seek actively as opposed to the act of memorizing repetitively".

In essence, inquiry is a process. This process starts from formulating a problem, formulating a hypothesis, gathering evidence, testing a hypothesis and drawing conclusions (Gulo, 2004). Inquiry learning strategies by using internet media are strategies where teaching and learning activities begin with the teacher delivering the learning objectives and motivating students to learn. Thus, this phase is followed by the presentation of information. Furthermore students are grouped in study groups. Then in the core activities, the teacher asks questions, suggestions for reading books, or other learning activities that lead to the preparation of problem solving, then students are given the opportunity to identify problem topics from the material discussed then formulated in the form of hypotheses as temporary answers. Furthermore, students collect relevant information to prove the truth of the hypothesis through internet media, then process the data and information that has been obtained, followed by careful examination to prove whether or not the hypothesis is set. Then close with drawing a conclusion.

Expository learning strategies are learning strategies that emphasize the process of delivering material verbally from a teacher to a group of students with the intention that students can master the subject matter optimally. This strategy has 4 principles, namely: (1) goal oriented, (2) communication principles, (3) readiness principles, and (4) sustainable principles (Sanjaya, 2008: 179). Furthermore, Killen (1998: 2) states that this expository learning strategy is termed a direct learning strategy (direct instruction). This strategy is based on the readiness of the teacher to provide all learning materials neatly, systematically and completely. The using of internet media on expository learning strategies are learning strategies that emphasize to the delivery of material verbally dominated by lectures by teachers to students with the aim that students master the subject matter. While the use of internet media generally takes place when students look for the answers to the assignments given by the teacher through guidance and direction from the teacher. Subsequently, students open the addresses of sites that contain the source of the subject matter being taught.

\subsection{The Nature of HOTS and LOTS Thinking Ability}

Thinking is the processing of various knowledge received by the five senses with common sense so that it can find answers to some truth. Husamah \& Pantiwati (2014), 
explained that thinking is a cognitive process that involves mental activities to gain knowledge through meaningful experiences. Someone's thinking ability can be divided into two, namely the high order thinking skills (HOTS) and the low order thinking skills (LOTS).

HOTS ability is the ability needed by someone to solve problems in daily life that starts from the ability to think logically, have preliminary knowledge related to the problem and can determine the right choice in overcoming the problems faced. Higher-order thinking skills are very important in the learning process in the classroom. Therefore, students who are trained will think and show a positive impact on the development of their education (Heong: 2011).

LOTS thinking according to Suryono \& Hariyanto (2014: 16), is the ability of students to think of the included aspects, such as remembering, understanding and applying (applying) included in the category of low-level thinking. HOTS based learning activities will be far different from LOTS based learning, following the differences expressed by Sani (2019: 62).

Table 2. Differences in LOTS and HOTS Learning activities

\begin{tabular}{|l|l|l|}
\hline No & \multicolumn{1}{|c|}{ LOTS learning activities } & HOTS learning activities \\
\hline 1 & Passive in thinking & Active in thinking \\
\hline 2 & Solve problem & Formulate problem \\
\hline 3 & Assessing simple problems & Assessing complex problems \\
\hline 4 & Convergent thinking & Divergent thinking and developing ideas \\
\hline 5 & $\begin{array}{l}\text { Learning from the teacher as the } \\
\text { main source of information }\end{array}$ & Finding information from various sources \\
\hline 6 & $\begin{array}{l}\text { Practice solving problems and } \\
\text { memorizing }\end{array}$ & $\begin{array}{l}\text { Thinking critically and solving problems } \\
\text { creatively }\end{array}$ \\
\hline 7 & Prioritizing factual & $\begin{array}{l}\text { Knowledge analytic, evaluative thinking } \\
\text { and making decisions }\end{array}$ \\
\hline
\end{tabular}

HOTS learning in the cognitive realm encompasses aspects of learning that enhance students' skills in analyzing, evaluating and creating.

\section{Research Methods}

This research was conducted in XI Social students in Senior High School State 1 in Pematang Siantar, T.P 2018/2019, at the amount of 114 people. This study used a pure experimental method with a $2 \times 2$ factorial design. Determination of the sample using is the Pruposive Sampling method and class grouping is done by ordinal pairing in order to obtain a sample of 60 people. The research instrument was in the form of a learning achievement test and a learning outcomes test questionnaire by a team of validators who had also been tested through validity, reliability, difficulty levels and different instruments.

Inquiry and expository learning strategies by using internet media as an independent variable, the ability to think as a moderator variable that is distinguished from HOTS and LOTS and economic learning outcomes are as the dependent variables. These variables can be seen in the table below. 
Table 3. The experimental design of $2 \times 2$ factorial design

Information:

\begin{tabular}{|c|c|c|}
\hline \multirow{2}{*}{$\begin{array}{c}\text { Thinking } \\
\text { Ability } \\
(\mathrm{B})\end{array}$} & \multicolumn{2}{|c|}{ Learning Strategies (A) } \\
\cline { 2 - 3 } & $\begin{array}{c}\text { Inquiry with Internet } \\
\text { Media }\left(\mathrm{A}_{1}\right)\end{array}$ & $\begin{array}{c}\text { Ekspository with Internet } \\
\text { Media }\left(\mathrm{A}_{2}\right)\end{array}$ \\
\hline $\begin{array}{c}\text { HOTS } \\
\left(\mathrm{B}_{1}\right)\end{array}$ & $\mathrm{A}_{1} \mathrm{~B}_{1}$ & $\mathrm{~A}_{2} \mathrm{~B}_{1}$ \\
\hline $\begin{array}{c}\text { LOTS } \\
\left(\mathrm{B}_{2}\right)\end{array}$ & $\mathrm{A}_{1} \mathrm{~B}_{2}$ & $\mathrm{~A}_{2} \mathrm{~B}_{2}$ \\
\hline
\end{tabular}

A : Learning Strategy

$\mathrm{B}$ : Thinking ability

$\mathrm{A}_{1}$ : Inquiry learning strategies using internet media

$\mathrm{A}_{2}$ : Expository Learning Strategies using internet media

$\mathrm{B}_{1}$ : High Order Thinking Skills (HOTS) Ability

$\mathrm{B}_{2}$ : Low Order Thinking Skills (LOTS) Ability

$\mathrm{A}_{1} \mathrm{~B}_{1}$ :Student economic learning outcomes taught by inquiry learning strategies using internet media to students who have High Order Thinking Skills (HOTS) capabilities

$\mathrm{A}_{1} \mathrm{~B}_{2}$ : Student economic learning outcomes taught by inquiry learning strategies using internet media to students who have Low Order Thinking Skills (LOTS) capabilities

$\mathrm{A}_{2} \mathrm{~B}_{1}$ : Student economic learning outcomes taught by expository strategies using internet media to students who have High Order Thinking Skills (HOTS) capabilities

$\mathrm{A}_{2} \mathrm{~B}_{2}$ : Student economic learning outcomes taught by expository strategies using internet media to students who have Low Order Thinking Skills (LOTS) capabilities

Hypothesis testing carried out in this study used a two-way variant analysis (ANAVA) technique by first conducting the normality test by using the Liliefors test and homogeneity using the F and Barlett tests. As for the formulation of the statistical hypothesis in this research are as follows:

Hypothesis $1: \mathrm{H}_{\mathrm{o}}: \mu \mathrm{A}_{1} \leq \mu \mathrm{A}_{2}$

$\mathrm{H}_{\mathrm{a}}: \mu \mathrm{A}_{1}>\mu \mathrm{A}_{2}$

Hypothesis $2: \mathrm{H}_{\mathrm{o}}: \mu \mathrm{B}_{1} \leq \mu \mathrm{B}_{2}$

$\mathrm{H}_{\mathrm{a}}: \mu \mathrm{B}_{1}>\mu \mathrm{B}_{2}$

Hypothesis $3: \mathrm{H}_{\mathrm{o}}: \mathrm{A} \times \mathrm{B}=0$

$$
\mathrm{H}_{\mathrm{a}}: \mathrm{A} \times \mathrm{B} \neq 0
$$

Informations :

$\mu \mathrm{A} 1$ : average student learning outcomes of inquiry learning strategies using internet media $\mu \mathrm{A} 2$ : average student learning outcomes of expository learning strategies using internet media $\mu \mathrm{B} 1$ : average learning of students who have HOTS abilities

$\mu \mathrm{B} 2$ : average learning of students who have LOTS ability

$\mathrm{AxB}$ : the interaction between inquiry learning models using internet media and students' thinking abilities

\section{Results And Discussion}

Based on the calculation results obtained that the research data were normally distributed, it can be seen in the table below 
Table 4. Summary of Normality Calculation Results

\begin{tabular}{|c|c|c|c|c|}
\hline No & Treatme t Groups & $\mathrm{N}$ & $\mathrm{L}_{\text {count }}$ & $\mathrm{L}_{\text {table }}$ \\
\hline 1 & $\mathrm{~A}_{1}$ & 30 & 0.130 & 0.161 \\
\hline 2 & $\mathrm{~A}_{2}$ & 30 & 0.154 & 0.161 \\
\hline 3 & $\mathrm{~B}_{1}$ & 32 & 0.126 & 0.156 \\
\hline 4 & $\mathrm{~B}_{2}$ & 28 & 0.136 & 0.167 \\
\hline 5 & $\mathrm{~A}_{1} \mathrm{~B}_{1}$ & 16 & 0.196 & 0.213 \\
\hline 6 & $\mathrm{~A}_{1} \mathrm{~B}_{2}$ & 14 & 0.196 & 0.227 \\
\hline 7 & $\mathrm{~A}_{2} \mathrm{~B}_{1}$ & 16 & 0.203 & 0.213 \\
\hline 8 & $\mathrm{~A}_{2} \mathrm{~B}_{2}$ & 14 & 0.191 & 0.227 \\
\hline
\end{tabular}

In the table above it is obtained that the data from each treatment group is normally distributed as seen from the $\mathrm{L}_{\text {count }}<\mathrm{L}_{\text {table }}$ at a significant level of $5 \%$.

Likewise with the homogeneity test, seen in table 5 below

Table 5. Summary of Homogeneity Test Results

\begin{tabular}{|c|l|c|c|c|}
\hline No & \multicolumn{1}{|c|}{ Treatment Groups } & Group & $\mathrm{F}_{\text {count }}$ & $\mathrm{F}_{\text {table }}$ \\
\hline 1 & $\mathrm{~A}_{1}$ and $\mathrm{A}_{2}$ & 2 & 1.674 & 1.861 \\
\hline 2 & $\mathrm{~B}_{1}$ and $\mathrm{B}_{2}$ & 2 & 1.742 & 1.878 \\
\hline 3 & $\mathrm{~A}_{1} \mathrm{~B}_{1}, \mathrm{~A}_{1} \mathrm{~B}_{2}, \mathrm{~A}_{2} \mathrm{~B}_{1}$ and $\mathrm{A}_{2} \mathrm{~B}_{2}$ & 4 & 3.23 & 7.81 \\
\hline
\end{tabular}

These results indicate that treatment group is homogeneous with Fcount $<\mathrm{F}$ table.

Hypothesis submission is done to prove the truth of the hypothesis that has been set so that it is obtained whether the hypothesis designed in the study is accepted or rejected. For the purpose of submitting hypotheses $2 \times 2$ factorial variant analysis (ANAVA) technique is then continued with Scheffe's further test since the number of respondents in each cell in anava is not the same two lines. The results of testing the hypothesis using SPSS version 25 can be seen in the table below.

Table 6. Summary of Anava Learning Outcomes on Economics Subject

Tests of Between-Subjects Effects

Dependent Variable: Learning.Outcomes

Type III Sum

\begin{tabular}{lllllll} 
Source & of Squares & df & Mean Square & F & Sig. \\
\hline Corrected Model & $353.662^{\mathrm{a}}$ & 3 & 117.887 & 22.449 & .000 \\
\hline Intercept & 428225.186 & 1 & 428225.186 & 81546.890 & .000 \\
\hline Learning.Strategies 26.076 & 1 & 26.076 & 4.966 & .030 \\
\hline $\begin{array}{l}\text { Thinking.Ability } \\
54.519\end{array}$ & 1 & 54.519 & 10.382 & .002 \\
\hline $\begin{array}{l}\text { Learning.Strategies } 260.743 \\
\text { * Thinking.Ability }\end{array}$ & 1 & 260.743 & 49.653 & .000 \\
\hline $\begin{array}{l}\text { Error } \\
\text { Total }\end{array}$ & 294.071 & 56 & 5.251 & & \\
\hline Corrected Total & 641432.000 & 60 & & & \\
\hline a & 647.733 & 59 & & & \\
\hline
\end{tabular}

a. R Squared $=.546$ (Adjusted R Squared $=.522$ ) 
In the table, it is noted that the results of the analysis of variance for learning strategies obtained $\mathrm{F}_{\text {count }} 4.966$ while the value of $\mathrm{F}_{\text {table }}$ with degrees of freedom $(\mathrm{df})=\mathrm{NK}(60-4)=56$ which is equal to 4013 , so $\mathrm{F}_{\text {count }} 4.966>\mathrm{F}_{\text {table }} 4.013$ at a significance 0.030 is smaller than 0.05 . Students' learning outcomes on Economics subject taught by inquiry learning strategies by using internet media obtained an average score of 86.10 which was higher than expository learning strategies by using internet media gained at an average value of 84.10 . These results indicate that the students' learning outcomes taught with inquiry learning strategies using internet media are higher than the learning outcomes of students who are taught with expository learning strategies using internet media which means that the research hypothesis is accepted. The results of this study are also in accordance with that conducted by Irmawati (2018) which states that the learning outcomes taught by inquiry strategy are higher than conventional ones as well as that of Chong (2017), showing an increase in students' learning outcomes by applying inquiry learning.

The results of the analysis of variance for the ability to think obtained was $F_{\text {count }} 10.382$ $>F_{\text {table }} 4.013$ at a significance 0.002 is smaller than 0.05 . Learning outcomes of students on economic subject who have the ability of HOTS had obtained an average value of 85.12 higher than the ability of LOTS who had obtained an average value of 83.75. These results indicate that the Economics subject learning outcomes of students who have high order thinking skills (HOTS) skills are higher than economic learning outcomes of students who have low order thinking skills skills (LOTS), which means that the research hypothesis is accepted. The results of this study are also in line with what was done by Alpindo (2014) that giving HOTS questions can improve the cognitive realm of students which is directly proportional to the increase in student learning outcomes. Fitriani \& Windayana (2015) also conducted research by addressing the results that HOTS can influence students' thinking abilities and learning outcomes.

Likewise with the results of the analysis of variance to see the interaction between learning strategies and thinking ability on economic learning outcomes obtained $\mathrm{F}_{\text {count }} 49.653$ $>\mathrm{F}_{\text {table }} 4.013$ at a significance 0.000 is smaller than 0.05 , it showed that there was an interaction between learning strategies and thinking ability towards learning outcomes economics, which means that the research hypothesis is accepted. The results of these interactions can be seen in figure 1 below.

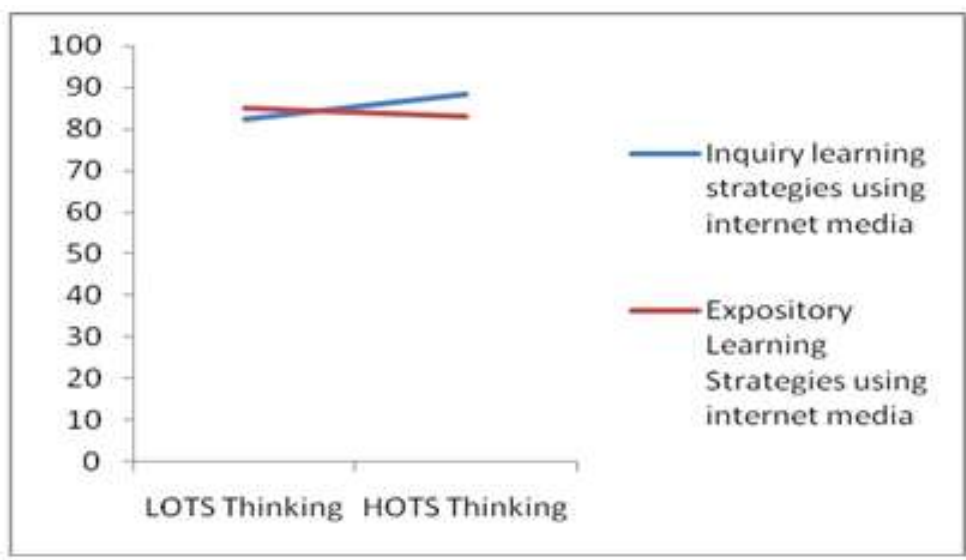

Figure 1. Interaction Learning Strategies and Thinking Abilities

Acceptance of the third hypothesis that there is an interaction between learning strategies and the ability to think of the Economics subject learning outcomes, it is necessary to do further tests to find out which average sample scores are influential. The follow-up test uses the Scheffe 
test because the number of respondents in each cell in anava two paths is not the same. The following summarizes the results of the Scheffe Test calculation can be seen in the table below:

Table 7. Summary of Scheffe Test Calculation Results

\begin{tabular}{|c|l|c|c|}
\hline No & Treatment Group & $F_{\text {count }}$ & $F_{\text {table }}$ \\
\hline 1 & $\mathrm{~A}_{1}$ dan $\mathrm{A}_{2}$ & 7.320 & 2.769 \\
\hline 2 & $\mathrm{~B}_{1}$ dan $\mathrm{B}_{2}$ & 10.493 & 2.769 \\
\hline 3 & $\mathrm{~A}_{1} \mathrm{~B}_{1}$ and $\mathrm{A}_{1} \mathrm{~B}_{2}$ & 52.709 & 2.769 \\
\hline 4 & $\mathrm{~A}_{1} \mathrm{~B}_{1}$ and $\mathrm{A}_{2} \mathrm{~B}_{1}$ & 46.086 & 2.769 \\
\hline 5 & $\mathrm{~A}_{1} \mathrm{~B}_{1}$ and $\mathrm{A}_{2} \mathrm{~B}_{2}$ & 14.930 & 2.769 \\
\hline 6 & $\mathrm{~A}_{2} \mathrm{~B}_{2}$ and $\mathrm{A}_{1} \mathrm{~B}_{2}$ & 10.832 & 2.769 \\
\hline 7 & $\mathrm{~A}_{2} \mathrm{~B}_{2}$ and $\mathrm{A}_{2} \mathrm{~B}_{1}$ & 7.264 & 2.769 \\
\hline
\end{tabular}

Based on these results it was obtained that $F_{\text {count }}>F_{\text {table }}$ so that each treatment group had a significant effect.

\section{Conclusions}

The conclusions in this study are as follows:

1. Students' learning outcomes on economics subject with learning strategies using internet media are higher than those who are taught with expository learning strategies using internet media. It can be seen that the $F_{\text {count }} 4.966$ while the value of $F_{\text {table }}$ with degrees of freedom $(\mathrm{df})=\mathrm{NK}(60-4)=56$ which is equal to 4013 , so $\mathrm{F}_{\text {count }} 4.966>\mathrm{F}_{\text {table }} 4.013$ at a significance 0.030 is smaller than 0.05

2. The learning outcomes of students on economics subject who have the ability to think High Order Thinking Skills (HOTS) are higher than those who have Low Order Thinking Skills (LOTS) abilities. This is evident from the results of the calculation of $F_{\text {count }} 10.382>F_{\text {table }}$ 4.013 at a significance 0.002 is smaller than 0.05

3. There is an interaction between learning strategies and thinking skills on student economic learning outcomes. This can be seen from the calculation results obtained Fcount $49.653>$ Ftable 4.013 at a significance 0.000 is smaller than 0.05

Implications that can be applied from the results of this study are:

1. Teachers can use relevant strategies in learning, one of them is inquiry learning strategies by involving the use of internet media in learning so that students can be active while training students to think by choosing relevant information.

2. The teacher can stimulate students' way of thinking through giving HOTS questions and always updating the latest economic problems faced by society and the country so that students' abilities are not only limited to theoretical knowledge but also the application.

3. Before the beginning of the lesson, it is necessary for the teacher to know the students 'initial thinking ability by giving a pre-test or questionnaire containing the students' thinking abilities. After that, the teacher can determine the appropriate strategy based on students' thinking abilities.

\section{References}

Alpindo, O., et al. 2014. Pengaruh Pemberian Pertanyaan Higher Order Thinking Skill (HOTS) Dalam Model Pembelajaran Problem Based Learning terhadap Hasil Belajar Fisika Siswa Kelas XI SMA N 2 Padang. Jurnal Pillar of Physics Education, 3: 113-120. 
Baker, W., et al. 2008. Writing to Learn in the Inquiry Science Classroom:Effective Stratagies from Middle School Science and Writing Teachers. Clearing House, 81 (3): 105-108.

Chong, J., et al. 2017. Implementing Inquiry Based Learning and Examining the Effects in Junior College Probability Lesson. Journal on Mathematics Education, 8 (2): 157-164.

Dwidayani, et al. 2013. Meningkatkan Hasil Belajar Mata Pelajaran IPS melalui Penerapan Model Inkuiri pada Siswa Kelas IV SD Inpres Bajawali Kecamatan Lariang Kabupaten Mamuju Utara. Jurnal Kreatif Tadulako, 3 (2).

Fadel, C. 2008. 21-st Century Skills : How can you prepare students for the new global economy? Paris: OECD.

Fitriani \& Windayana. 2015. Pengaruh HOTS melalui Model SPPKB pada Pembelajaran Matematika terhadap Kemampuan Berpikir Kreatif Siswa. Jurnal PGSD Kampus Cibiru, Vol. 3 (2).

Gulo, W. (2004). Strategi Belajar Mengajar. Jakarta: Grasindo

Heong, Y.M, et al. 2011. The Level of Marzona Higher Oreder Thinking Skills Among Technical Education Students. International Journal of Social and Humanity, 1 (2): 121- 125.

Husamah \& Pantiwati, Y. 2014. Coorperative Learning ATAD-PjBL: Motivation Thinking Skills and Learning Outcomes in Biology Students. International Journal Of Education Learning \& Development (IJELD), 2 ( 1): 77-94.

Irmawati, R. D., et al. 2018. Higher Order Thinking Skills (HOTS) dalam Pembelajaran IPA Siswa Kelas IV Sekolah Dasar. Jurnal Tunas Bangsa, 5 (2): 143-156.

Kemdikbud. 2014. Materi Pelatihan Guru Implementasi Kurikulum 2013. Jakarta: Kemdikbud.

Killen, R. 1998. Effective Teaching Strategies: Lesson from Research and Practce, second edition. Australia : Social Science Press.

Marshall, J.C \& Horton, R.M. 2011. The Relationship of Teacher Facilitied Inquiry Based Instruction to Student Gigher Order Thinking. Jounal of School Science and Mathematic, 3: 93-101.

Miarso, Y. 2009 Menyemai Benih Teknologi Pendidikan Jakarta: Kencana Prenada Media Group.

Ozad \& Kutoglu. 2010. The Use of The Internet in Media Education. The Turkish Online Journal of Educational Technology (TOJET), 9 (2): 245 - 255.

Rusman. 2012. Model-model Pembelajaran. Depok. Rajagrafindo Persada.

Sani, R.A. 2019. Pembelajaran Berbasis HOTS (Higher Order Thinking Skills). Tangerang: Tira Smart.

Sanjaya, W. 2008. Strategi Pembelajaran Berorientasi Standar Proses Pendidikan. Jakarta: Kencana Prenada Media Group

Suparman, A.M. 2012. Panduan Para Pengajar dan Inovator Pendidikan: Desain Instruksional Modern. Jakarta: Erlangga.

Suryono \& Hariyanto. 2014. Belajar dan Pembelajaran: Teori dan Konsep. Bandung: Remaja Rosdakarya.

Yusuf, M.A. 2015. Asesmen dan Evaluasi Pendidikan. Jakarta: Prenadamedia Group. 